\title{
Role of Media in Representation of Sociocultural Ideologies in Aurat March (2019-2020): A Multimodal Discourse Analysis
}

\author{
Fatima Zafar Baig ${ }^{1}$, Muhammad Zammad Aslam², Nadia Akram ${ }^{1}$, Kashaf Fatima ${ }^{1}$, Alisha Malik ${ }^{1}$ \& \\ Zafar Iqbal ${ }^{3}$ \\ ${ }^{1}$ National College of Business Administration \& Economics, Multan, Pakistan \\ ${ }^{2}$ National University of Modern Languages, Islamabad, Pakistan \\ ${ }^{3}$ MPhil Scholar, Minhaj University, Lahore, Pakistan \\ Correspondence: Muhammad Zammad Aslam, National University of Modern Languages, Islamabad, Pakistan. \\ E-mail: zammad.aslam@gmail.com
}

\author{
Received: December 17, 2019 Accepted: March 10, 2020 Online Published: March 18, 2020 \\ doi:10.5539/ijel.v10n2p414 \\ URL: https://doi.org/10.5539/ijel.v10n2p414
}

\begin{abstract}
The researchers have explored the role of print media and social media to present the social, cultural and political ideologies through the support of liberal feminist women in Aurat March 2019-2020. Moreover, the researchers have identified the connection/s between the language and power in the construction of ideologies, specifically through the media (print and social media). Print media, specifically print social media, has a negative impact due to its lesser amount of validity and a positive keeping wide coverage. For this study, researchers took three articles from three different local newspapers about the specific topic "Aurat March". These articles along with the posters (which were present in the specific articles) of Aurat March have been analyzed. The researchers collected the data through a qualitative approach and purposive sampling. The research is exploratory and multi-directional. Fairclough's model of critical discourse analysis is used for the analysis. The findings of the study have suggested that media discourse is intentionally crafted to create specific ideologies. As media has created and represented different socio-cultural ideologies in Aurat March. Media can play a positive and negative role in language and power. However, the impact of the media's ideologies is depending on the feedback of the concerned society.
\end{abstract}

Keywords: discourse, media discourse, print media, language, power, ideology, Aurat March, critical discourse analysis

\section{Introduction}

Media has an important role to impose its thoughts to the public by manipulating their minds (Baig et al., 2020). It is helpful to maintain social control by formatting social thought according to the ideology of the ruling (Akhtar et al., 2020, p. 365). In democratic countries, the free media is regarded as the "fourth estate" besides the legislative, executive and judiciary branches. More than just a source of entertainment, mainstream media is a powerful communicator of cultural norms and values which defines the world and legitimize the social order utilizing language as social power (Fairclough, 2001 as cited in Akhtar et al., 2020, p. 365), and language is seen as a multi-layered means of communication (Sibtain et al., 2020, p. 349) through which every communicate his/her message with audience. Happer and Philo (2013) has argued that media influences on society in so many ways. It helps the people to get information about a lot of current issues and affairs and makes judgments regarding various problems related to society, which keeps the people updated and informed about what is happening around them and the world. While, the movement of Aurat March is referring to a series of campaigns for reforms the problems of the society, such as women's suffrage, reproductive rights, domestic violence, and equal pay in the workplace, maternity leave, sexual harassment, and sexual violence. The following research is focusing on the role of media in representation of different ideologies represented and constructed in Aurat March through power and language. So, women, from all over the country, are standing against the patriarchal social system for their basic rights. In this research, the role of media is explored to represent and construct different sociocultural ideologies in Aurat March 2019-2020.

\subsection{Language, Ideology and Media Discourse}

The mass media (social media in case of Pakistan) has influenced the political, social, economic, cultural 
ideologies and vice versa. Therefore, various intuitions in power are controlling the media through the ideological or repressive state apparatuses (Fairclough, 2001; as cited in Sabir \& Kanwal, 2018). So, information through media can involve the ideologies that people of the society aware of the society. However, media cannot often represent the original reality, yet, disguised reality or readymade representations of reality. Furthermore, Sara Mills (2008) has stressed the reception and feedback of the audience while analyzing the text discourses. For instance, reading and analysis of a text are equally important to explore the ideologies presented in the text. Our experiences of daily life, our way of thinking related to various things or our social interactions can shape the language as a living being that remains in flux (Montgomery \& Feng, 2016). So, culture always can produce and modify the language. Therefore, people of different cultures can develop/modify/re-shape the social process that is deeply interwound with society (Wodak, 1999). Mills (1995) has argued that discourses as a knowledge system in human society, in which, human utilizes discourse power to gain or to remain in power or to remain at a power position. For instance, discourse is a power through which people dominate other people, yet, the control of the power always remains in the hands of powerful, and this power would be seized by the utilizer, so, the discourse could also be considered a struggle to gain power or to remain in power (Mahmood, Javid, \& Mahmood, 2011). Therefore, the discourse practices and discourse analysis are important, through which the individuals produce/reproduce ideologies while analyzing ideology employing discourse theories. The understanding of traditional ideology by Marx is distinctive from the contemporary Althusser's concept of ideology in which the real relationships wearing masks are often worn imaginary relationships amongst the individuals. For instance, the realities of real-life are often represented through the imaginary practices of discourses (Mahfouz, 2013). Here, we can say that social relationships are often recognized through the distorted imaginary ideology system, for instance, the ideology controls every type of concept which works/exercised-works through ideological and repressive state apparatus respectively. Moreover, media (other sources) can take apart into ideological state apparatus, and security forces can involve in repressive state apparatus, and both apparatuses are often exercised by the elite in power consciously/unconsciously to control the ruled groups. Therefore, legalization, or digitization, or distorting relationships of the society are often maintained and controlled through the process of asymmetrical relations by the dominating elite groups through ideological systems (Wodak, 2002). Through exclusion, stereotyping or discrimination, media often propagates/repropagates the ideologies of the dominant groups of the society. For instance, in the present case, media (social media) propagates/repropagates the ideologies of the so-called liberal elite class of Pakistan highlighting the women's oppression, and violence against women yet in anti-social discourses (in form of banners).

\subsection{Purpose Statement}

The purpose of this research is to show the role of media in developing dominant socio-cultural ideologies. Media can play an important role in creating different ideologies in people's minds. By keeping in mind, the political, social and cultural background of the area, media can develop the news according to that background. The language used in the media can easily manipulate people's minds. So, the purpose of this research is to explore and identify different kinds of ideologies constructed through media in Aurat March. It also aims to identify the language and power in it, so that it can be said that somehow there is the role of media in manifesting power relations.

The objectives of the study are to examine the role of media in representing socio-cultural ideologies through the posters of Aurat March; to investigate the role of media in the construction of ideologies through language and power.

The present researchers have tried to answer; What is the role of media in representing socio-cultural ideologies through the posters of Aurat March? How the media construct different ideologies by language and power?

The significance of this research is that it focuses on the construction of ideologies in media. This research analyzes the different posters of Aurat March that were shown on media. The study also gives an approach to the three-dimensional model of Fairclough and its application on posters. Media influence is the actual force exerted by a media message, resulting in either a change or reinforcement in audience or individual beliefs. Its texts always reflect certain values or ideologies. The media is a successful carrier of ideology because it reaches such a huge audience. The study of the media allows us to consider and question dominant ideologies and look for the implications of different ideologies and value systems.

\section{Theoretical Framework}

\subsection{Critical Discourse Analysis}

Critical Discourse Analysis (CDA) has much promise for educational research. Researchers using CDA can describe, interpret, and explain the relationships among language and important educational issues. It is because 
CDA can raise important social issues, that it is worthwhile trying to strengthen its analyses. CDA has defined that there are relationships among language, power, and ideology as well as between how the world is represented in texts and how people think about the world (Baig et al., 2020, p. 70). CDA discusses how discourse is shaped by power and ideologies, and how discourse influences social identities and systems of belief. Language use is both "socially shaped and socially constitutive" (Fairclough, 2001), for instance, Fairclough (1992) argues that people understand each other's actions through discourse as a responsibility (Aazam et al., 2019, p. 192; Baig et al., 2019, p. 70; Sibtain et al., 2020, p. 350). In this research, the posters and lines from the articles are analyzed by critical discourse analysis. The Fairclough model can be used with different dimensions for its critical analysis, which are; Description. Text analysis, Interpretation. Processing analysis/discourse analysis, Explanation. Social analysis/cultural analysis (Baig et al., 2020, p. 72).

\subsection{Social Constructivism}

The ontological viewpoint held as a basis for this study is social constructivism. The basic idea of social constructivism is that the world is socially constructed. The social order in which we perceive the world, what is right or wrong, is in a constant state of change. Meaning is constructed through interaction between different people and their relation to objects and other people. Definitions and concepts are also constantly changing, depending on the current culture, and it is also varying from situation to situation (Bryman, 2008). What this means is that meaning is created through language depending on how people use concepts and what the meaning of these concepts are. The following quote describes it perfectly,

It is social actors who use the conceptual systems of their culture and the linguistic and other representational systems to construct meaning, to make the world meaningful and to communicate about that world meaningfully to others (Hall, 1997).

\subsection{Feminist Theory}

The theory used in this study was the Feminist Theory of Mills (2008; as cited in Darweesh \& Ghayadh, 2016). Feminist Theory emerged as a result of political movements to end female's subordination with families as well as in other institutions, beginning in the late nineteenth century. Feminist theory suggests that the concept of cultural gender, defined as all the learned and cultural phenomena loosely associated with biological gender, is socially constructed. Traditionally, females have been defined as ideologically by cultural norms and gender.

According to Feminist Theory, cultural or symbolic notions of gender determine what it means to be a male versus a female in a specific sociocultural context. Feminist Theory has suggested that sexuality is symbolically charged, deeply embedded in social institutions. It further has suggested that it is a culture that constructs the separated sex categories, "male and female" and gendered notions like "masculinity and femininity".

\subsection{Related Researches}

For a clear understanding of the present topic of the research, the researchers have discussed some of the researches in this section of the research. The first research, Hassan (2008) explores the ideologies hidden in the language of media. For instance, the researcher analyzed the construction of ideologies in the newspaper specifically in the headlines in Pakistani newspapers. Moreover, the researcher analyzes the impact of these ideologies on the minds of readers. Moreover, these ideologies are explored employing the CDA model/framework described by Fairclough (2001) on the text and discourse of three diverse Pakistani news channels. For the intertextual and sociocultural interpretation and analyses, the researcher utilizes a questionnaire to collect and record the perceptions and views of the real audience and viewers concluding varying ideologies and power relations, hence, the responses of the viewers reveal their dislike for entertainment-oriented, exaggerated, unfair, and moderately informative headlines of news channels (Hassan, 2008). Sometimes the informational content on the media outputs is ideologically shaped. The purpose behind this ideologically driven information is to reproduce and strengthen the social relations of oppression and exploitation (Tolson, 1991 as cited in Hassan, 2018).

The other research is about the representation of gender roles in the media It influences both how we see ourselves and the world to some extent. There are many different types of media, for example, television shows, movies, the radio, newspapers, advertisements which are placed in random places and the internet. In these different forms of media, there are images of men and women, which are represented in different ways and with different characteristics. Research has been made on a lot of movies and television shows and this thesis will be adding to this vast amount of research by analyzing gender representation in the movies Sex and the City 1 and 2. By using discourse analysis, the results show different types of gender representation and whether the characters in Sex and the City challenge the patriarchal privilege. Assuming social constructivism, it is believed that these images of 
gender representation in movies affect our perception of what a man or a woman is. The results suggest that the characters do still follow the patriarchal privilege, but some characters do on occasion challenge them. However, the outcome is rarely successful (Ottoson \& Cheng, 2012). In this recent research, we explore how media plays a role in the construction of different ideologies and how language changes the views and opinions of viewers, listeners, and readers.

\section{Research Methodology}

The study adopted the exploratory design. In such research designs, truth is multilayered and multidimensional (adapted from Baig et al., 2020; Sibtain et al., 2020; Aazam et al., 2019, p. 192; Baig et al., 2019). Furthermore, the qualitative method was used to collect and analyze the data. The population of the study is articles and posters of Aurat march. The sampling of the study was probability sampling. Therefore, keeping research in mind, the sample has been drawn through random sampling which is a type of probability sampling. The data are collected from the articles written on Aurat March. There are three articles taken as data and lines, phrases and posters from those articles are analyzed to explore the role of media in construction and representation of ideologies in Aurat March. The data analysis is based on Fairclough's critical discourse analysis framework (2001). His three-dimensional framework includes the conception of discourse as a text (micro-level), discourse practice (Meso level) and sociocultural practice (macro-level) (Baig et al., 2020, p. 72). The main purpose is to inquire about the connection between language, ideology, and power and explore out how media constructs and represents different socio-cultural ideologies. Among all the articles and posters used in them are randomly selected and analyzed.

\section{Data Analysis}

This chapter includes the analysis of articles. The analysis is done in the light of Fairclough model critical discourse analysis.

\subsection{Analysis of Article 1}

This article has been taken from the Jasarat newspaper from its Friday special edition. There are lines, phrases, words and posters (which are present in this article) that are representing different socio-cultural ideologies. The title of the article is "Aurat March! Secular or liberal dehshatgardi" (trans. Aurat March! Secular and liberal terrorism) and it is representing that Aurat March is against religious values, it is not holding its religious values and it is open terrorism against the state religious values. This march was done in Pakistan and Pakistan is a religious Muslim country, so that the choice of words of the title is against the sociocultural background of the country. So, the writer of the article is representing the cultural, social and religious ideologies of the Pakistani society. For instance, in Pakistan, all the communities of different religions are not supporting this march because their cultural values cannot allow them to support it. Fairclough (1975) has stated that

"Pakistan $k$ "jadeedzadgaan" aksar ye baat kehtay hain kay jadeediyat ka matlab maghribyat yani "Modernization" ka mafhoom "westernization" nahi hai. Lekin ye ek sarih ghalat biyani hai jo awaam o khaas ko dhoka deny kay liye ki jati hai, warna asal baat ye hai kay jadeediyat maghrbiyat kay siwa kuch nahi balkay Karachi, Lahore or Islamabad main hony waly naam nihaad Aurat March say sabit ho gya kay Modernization maghrbiyat say agay barh kar vulgarization balkay dehumanization bhi ban skti hai." (trans. The "modernist" of Pakistan often say that modernity does not mean westernization, but this is a blatant misinterpretation that is made to deceive the public. Otherwise, the point is that modernity is nothing but westernization. The so-called Women March 8 in Karachi, Lahore, and Islamabad have proved that modernization can transform westernization vulgarization but also dehumanization" (as cited in Sabir \& Kanwal, 2018).

The whole text is written in the Urdu language but there are words like "Modernization, Westernization, Vulgarization and Dehumanization" are written in the English language. The code-switching technique is used. The word switching technique is used to make the text more appealing and to bring the stress on the switched words.

The Aurat March is interpreted as the devaluation of human values. Most modern people in Pakistan say that modernization is not westernization but as it is ignoring our moral values it is spreading vulgarity. Pakistan is known to be an Islamic country. The word so-called is used for the Aurat March which interprets that it was nothing but vulgarity and dehumanization. It is bringing the political propaganda of western countries.

In Pakistani society, the word modernization is associated with westernization. Whoever speaks about modernism, in sociocultural terms it is taken as westernization. And westernization is thought to be the de-valuation of moral values. In the sociocultural context, modernization is the term used by modern people, who wants to change the social values and behavior. On 8th March Aurat March was held, so as women are known to less privileged, when 
they came out of the house for March in the name of modernization their March is spread vulgarity. It promoted the western agenda. It represents the ideology of the mindset of the public about westernization, which is linked with vulgarity. It also represents the ideology about the beliefs that if Aurat March is held was held it is the dehumanization of humanity. It brings human and social values down. Aurat March tried to bring modernization in a country that promotes the agenda of westernization and westernization is the main cause of vulgarism and in turn which somehow brings the dehumanization and denial of humanity. Fairclough (1975) has stated that media is a mode of imposing the ideology on the mine of people, but it depends on the feedback of the people of such a community. If the feedback positive, the ideology of media is accepted by the society, if the feedback is negative then the media unable to impose the ideology (Sabir \& Kanwal, 2018). So, the Aurat March cannot impose the ideology behind it due to the negative feedback of the Pakistani society.

\subsubsection{Posters of Aurat March}

The researchers have analyzed the following poster by keeping in mind the socio-cultural background and ideologies of the Pakistani community. Social ideologies are identified and the role of media and power in positioning them is explored.

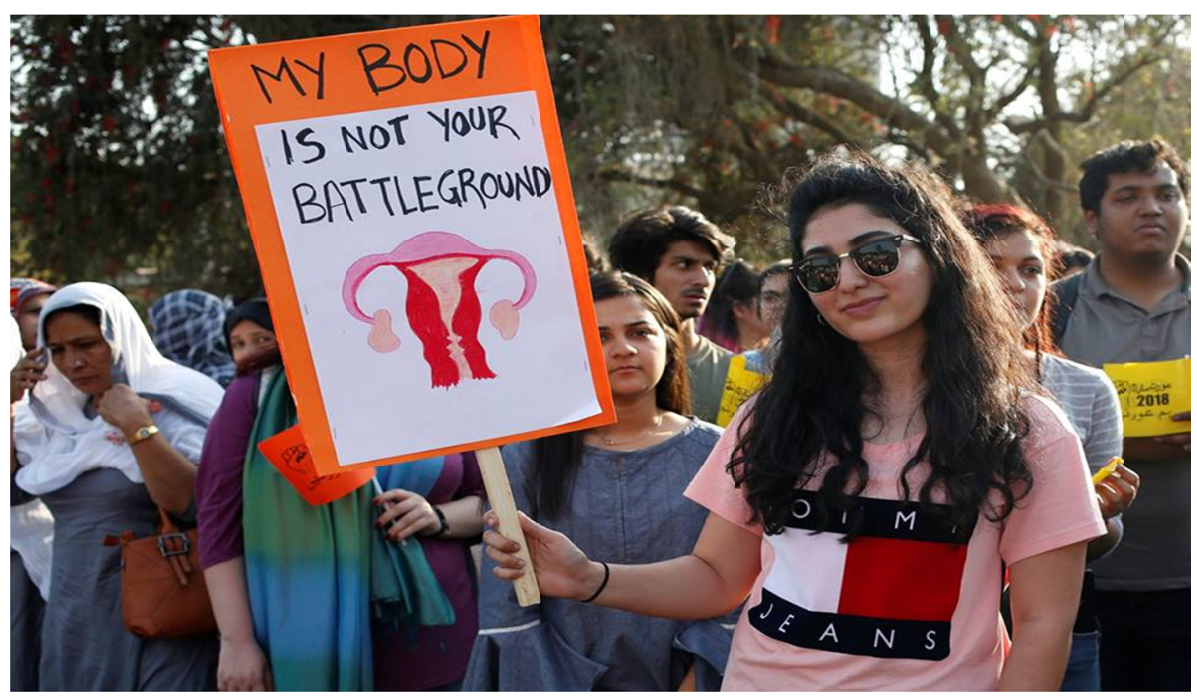

Figure 1. My body is not battleground

\section{Analysis}

As far as the description of the poster (Figure 1) is concerned, a girl is holding the poster. The message of the poster is "MY BODY IS NOT YOUR BATTLEGROUND" which is written in bold letters to give stress upon the subject matter. To make the poster more prominent, there is a picture of the woman's private part (uterus). The choice of words is appealing.

The figure (Figure 1) is interpreted on different levels. As the word "BATTLEGROUND" is used for a place or situation of conflict or strife. Here word body is used as the battleground where one fights and argues. This poster can also be interpreted that it is inspired or taken from the "Mohja Kahf" poem who is a Syrian-American poet. She expresses in this poem that how bodies of women are so often controlled, not just physically but also how they are represented. She states that women need to define their image themselves and others should not stereotype them but allow women of each ethnicity to define their own identity. The image of women's reproductive organs on posters expresses the self-representation of women about their bodies.

In a patriarchal society, mostly women body is treated as an object of sex. This poster is representing the ideology of women's bodies being treated as objects of sex. Women tend to be a weak human being on which the aggression and frustration can be thrown. In sociocultural context 'BATTLEGROUND' is the word which is used for a place for the battles and wars. The image of the sex organ identifies the women's body being treated for sexual violence. Sexual violence signifies the limited and inadequate control of women on their bodies in society. In the above-depicted poster, the young lady is protesting against sexual violence by the male society. Such as ideology can be presented through the visual and written language that can be interpreted through the Fairclough (1975), 3D 
model. For example; Fairclough (1975) has stated that people can communicate through the visual and written language which can be understood through identifying the social context of the language (Sabir \& Kanwal, 2018).

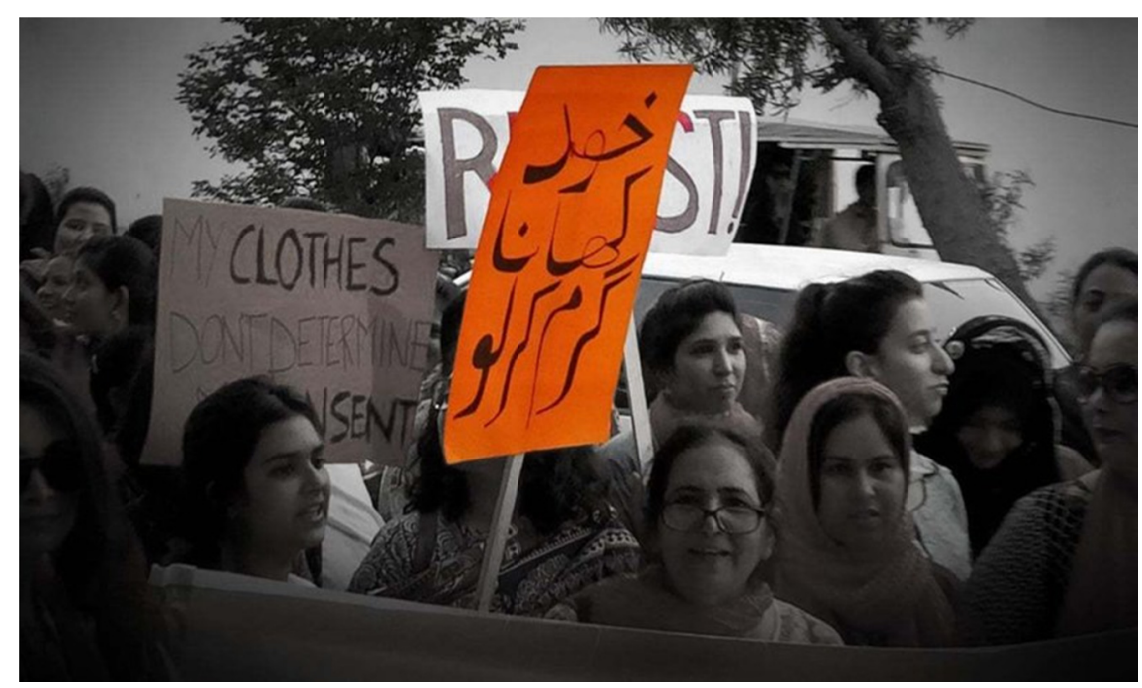

Figure 2. Khana khud garam karlo

Note. Main text: Khana khud garam kro; Translation: Heat your food.

\section{Analysis}

In the description, the poster understudy is showing a black and white background, While the main figure has a colorful description to focus on the main message. The message is written in the Urdu language. The message focuses on the independence of others to heat their food and does not depend on women for this. It is interpreting that men should not depend upon women for doing their daily life chores, even for heating the food it is thought to be the duty of women to heat the food for their men. Sara Mills (2008; as cited in Darweesh \& Ghayadh, 2016) has argued that women can get red from the cruel attitude of the men by raising their voices.

In Pakistan, home chores depend upon and it is expected from women to be responsible for all the work at home. It also represents the ideology that women are responsible for all the work of men in the home. When men come from outside it is expected from women to heat food for them and serve them. So, they are here asking men for being responsible for their works and heat their food.

In the article, it is told to be the start of modernization which in return leads dehumanization. These posters reached the readers through media and then the media represent different ideologies. As these posters are taken from the article, which is a form of print media, they create different ideologies. However, in the target society, these kinds of ideology cannot be imposed because these ideologies are against the social context. Fairclough (2001) has stated that we can judge the ideology behind the text through its value before the society (Sabir \& Kanwal, 2018) 


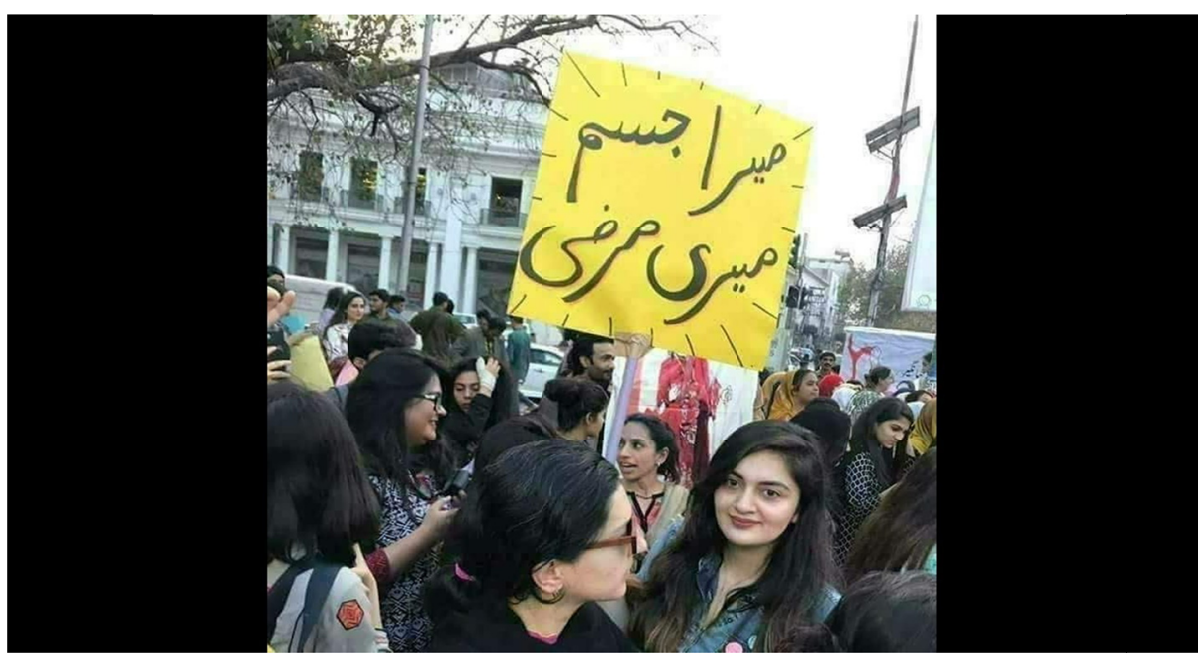

Figure 3. Mera jism meri marzi

Note. Main text: Mera jism meri marzi; Translation: My body my choice.

\section{Analysis}

The text is written in the Urdu language. The poster is in yellow and the main message is written in black color to make the message prominent. The language of the poster is bold. It is interpreted as the society holds control on women's bodies mostly as told in Figure 1, the women are considered mostly restricted to make decisions about themselves, yet, by a few elite/civil society's women. Some of these types of women often argue that women body is objectified whether as sexual violence, physical violence or for her clothing style. On the other hand, most of the women of the society follow the cultural and religious values of the society, so, they don't oppose their roles that they have assigned them culturally. Culture and religion also allow women to work outside the house if they need to do it. Hence, the activists and feminists argue that women's body is acknowledged by men, for instance, according to them, the slogan (in Figure 3) represents the social and cultural ideology about women body that how their body is criticized on the public level, that could be body shaming, fat shaming, etc. Therefore, the slogan has put a negative impact on society because the feedback of the people of that society is negative (Fairclough, 2001).

The slogans are often reached in public through media and media represent the socio-cultural ideologies about women's body and self-representation of women. In Pakistan, due to its cultural values, women cannot speak openly about their bodies. According to the first article, there is an effect of westernization in the slogan which is thought to be leading towards vulgarity. Because in the west people are more open about their bodies and self-representation. So, promoting this slogan is thought to be the propaganda of promoting westernization. However, western society never promoted the things which are against the general ethics, so that in this article, the writer is arguing that this March is beyond Westernization yet, it is Vulgarization and Dehumanization.

All the posters that are analyzed and mentioned above are present in the article which is through media reaches to audiences. The media represents different socio-cultural ideologies about them. Furthermore, the text of the article says about the posters is:

"Jaisa kay humnay arz kia kay in naaron main bat Westernization say agay barh kar Vulgarization bulky Dehumanization tak chli gai hai. Aurat March main ek sahib say yeh tak kehlwa dia kay jab tak nikkah ka idaara khtum ni hoga tab tak Aurat ko zulm say nijaat nhi milay ghi." (trans. As we said before the talk in these slogans goes beyond Westernization to Vulgarization but also Dehumanization. In March a man was told to say that a woman would not be saved from oppression until the institution of marriage is over.)

The foreshadowing technique is used in the text. The whole text is written in the Urdu language, but words like 'Westernization', 'Vulgarization' and 'Dehumanization' are written in English to put the stress upon the words. The text is showing the ideology that there was an impact of western culture on the Aurat March. As western are more open in their culture and civilization (e.g., they are not affected by the women dress or sits). When their culture is being followed in Pakistan it brings Vulgarization in the community because here the women are noticed majorly for everything (e.g., their sitting style, talking style, clothing, etc.). when women followed their culture, it brings shame and vulgarity in the society and it dissolute the human value of culture and causes dehumanization. The human and gender roles are not performed accordingly which causes a disturbance. A man in March said that 
marriage institute should be diminished because it brings trouble for women, it interprets that men were present in the march but when it was said the marriage institute should be over it was because of women. Women made him say about the abolishment of Nikah. In Pakistani society, which is considered as an Islamic society, there are rules of Islam are followed, when the women carried Aurat March they bring the Islamic values down. And marriage is one of the main Islamic duties, on which they talk about its abolishment which represents the demoralization of moral values. It is considered as pure relation the Aurat March didn't give it respect. According to sociocultural values marriage brings safety and completion in a relationship, but as there is a strong impact of the west in Pakistan the western values are being promoted here which means vulgarity is accumulating.

In this article, Aurat March 2019 and 2020 are shown to be the event that has torn apart the cultural and social values of society. The media represents the ideology about Aurat March and its slogan to because of fuss and controversy in the nation.

\subsection{Analysis of Article 2}

The name of the second article is "Aurat Azadi March ky naam pr ghinona khel be niqab" (The filthy game is exposed in the name of Aurat independence March). The title of the article itself is revealing the text of the article. Aurat March is compared to the filthy game. There is a use of curse words. The title can be interpreted as the women played a filthy game and named it as independence March. In the socio-cultural context, the word filthy is used for something dirty, shabby and sleazy. In Pakistan, women are not expected to come out of home marching for their independence and rights. It is against the social and cultural odds. The title represents the ideology that if women come out of their houses marching it must be their filthy game to ask for rights in a way like this: for instance, "Aurat March kay naam par 8 March ko Pakistan k chand bary sheehron main jo kch hua usky khwateen kay haqooq kay sath to kia talluq hona tha, lekin besharmi, begairti or fahashi kay farogh sy talluq zroor tha" (trans. What happened in some major cities of Pakistan on March 8th in the name of women freedom march had nothing to do with women's right but shamelessness, immodesty, and vulgarity).

The whole text of the article is in the Urdu language. On 8th March women of Pakistan carried an Azadi (independence) March for asking their rights. The text can be interpreted as the March that women carried was nothing less than the promotion of vulgarity and shamelessness. It is bringing nations towards immodesty and vulgarism. In sociocultural context, there are boundaries for males and females. 8th March that is international women day, so the women of Pakistan also came out from their houses marching for their rights. But it was more like the promotion of vulgarity in the country: for instance, while comparing Aurat March with the principles of Islam, the writer states, "Aurat kay haqooq aur azaadi niswa kay naam par esa mazmoom kheel khela ja rha hai jis ki naa to hamary deen main koi jagah hai or naa hi hamaray muashrti iqdaar is beshrmi ki ijazat dta hai" (trans. In the name of rights of women rights and freedom, there is such a ridiculous game being played that has no place in our religion and none of our social norms allow this), however, Islam is a religion that protect the right of women and never allows the men to deprive the women of her basic right. Moreover, the so-called Aurat March is promoting the vulgarity rather than protecting the basic human rights of the women.

The term used for Aurat March by the writer is "mazmoom khel" which is translated as a ridiculous and foolish game. The word 'game' is often used for the activities done just for fun and enjoyment. Then he compares Aurat March with religion by using the word 'hamaray deen' (our religion) that can be interpreted as the writer's effort for creating unity between him and his readers as to develop a collectiveness of opinions. By religion, he is saying about Islam because Pakistan is an Islamic country where the majority of the population is Muslim. Further, the writer tries to represent Aurat March as something that is against the values and permission of society by using the words 'none of our social norms allow this'. This text can be interpreted as it's an effort to portray Aurat March a childish, foolish play in the shade of women's rights that means it is a kind of mockery which is neither allowed by religion nor by society. In Pakistani society, the rights and freedom of women are mostly determined by religion and society. So, asking for something other than that is considered as a 'mazmoom khel (foolish play)'. These lines by the writer create and present the ideology that this type of March is against the religion and people of Pakistan.

Then he talks about the purpose of Aurat March and hidden agenda behind this act: "Is trha kay "afkaar" say subko pta chal gya kay iss show ka maqsad hamary deeni or muashrti iqdaar or family system ko tabha o barbaad krna hai" (trans. Such 'mindfulness' made everyone aware that the show is aimed at destroying religion and social values and the family system).

Before this, the writer writes a statement of a man who took part in Aurat March, where he says that the problems of women cannot be solved until the 'Nikah' is abolished and we should end the 'Nikah' to end the injustice and oppression of women. The word used for marriage is very specific 'Nikah'. It is an Islamic term used for marriage. The writer's use of this word in this article may be to highlight that people marching for this March wants to 
demolish it. Further, he calls out this statement as not only the opinion of one man but a mindfulness of the whole March participants by using the word 'afkaar' which means collective belief. Then, the purpose of the March is described as the destruction of 'deeni or muashrti iqdaar or family system' religion and social values and the family system. This text can be interpreted as an effort to present Aurat March as a show. If the women are raising their voices against gender discrimination, then they are corrupting the family system and destroying social values. In the sociolinguistic context, these lines represent the ideology about the women standing against their cultural values: for instance, "khawateen nay iss naam nihaad aurat ki azaadi ko kuch is tarha mustarid kia kay ek sahafi Javeria Siddiqui ny apny twitter paigham main likha kay 'main aurat hoon or mujhy apny mazhab, tehzeeb or saqafat sy bahir azaadi darker nhi." (trans. Women rejected this so-called woman's freedom in a way that journalist Javeria Siddiqui wrote in her twitter message 'I am a woman and I don't need any freedom outside the boundaries of my religion, tradition, and culture).

Here the words to be focused on are 'rejected', 'so-called' and 'journalist'. The word 'rejected' is used to present the reaction of other women and condemnation for this Aurat March. The concept of Aurat March is shown as a 'so-called' way of getting freedom for women, which is to say, a pointless and worthless. To support the writer's stance, he uses a statement of 'Journalist' Javeria Siddiqui. Mentioning this specific journalist may be to reveal that even women are against this March. The text interprets the even women are not accepting this open so-called freedom which is culturally against their social values. Even famous women, who are well-educated, are standing against this March. Pakistan has a patriarchal society, so women are expected to behave within their social and cultural boundaries. The tweet that is mentioned in the article is tweeted by famous journalist Javeria Siddiqui which states that "I am women" and despite being a woman "I don't need any freedom outside the boundaries of my religion, tradition, and culture." Here she represents the ideology of Pakistani women about their freedom and rights that the rights they have are enough for them. The purpose of referring this tweet in this article may be to build the ideology of showing Aurat March as unacceptable and unworthy even by other women.

The slogans of Aurat March about which writer is talking about are the following:

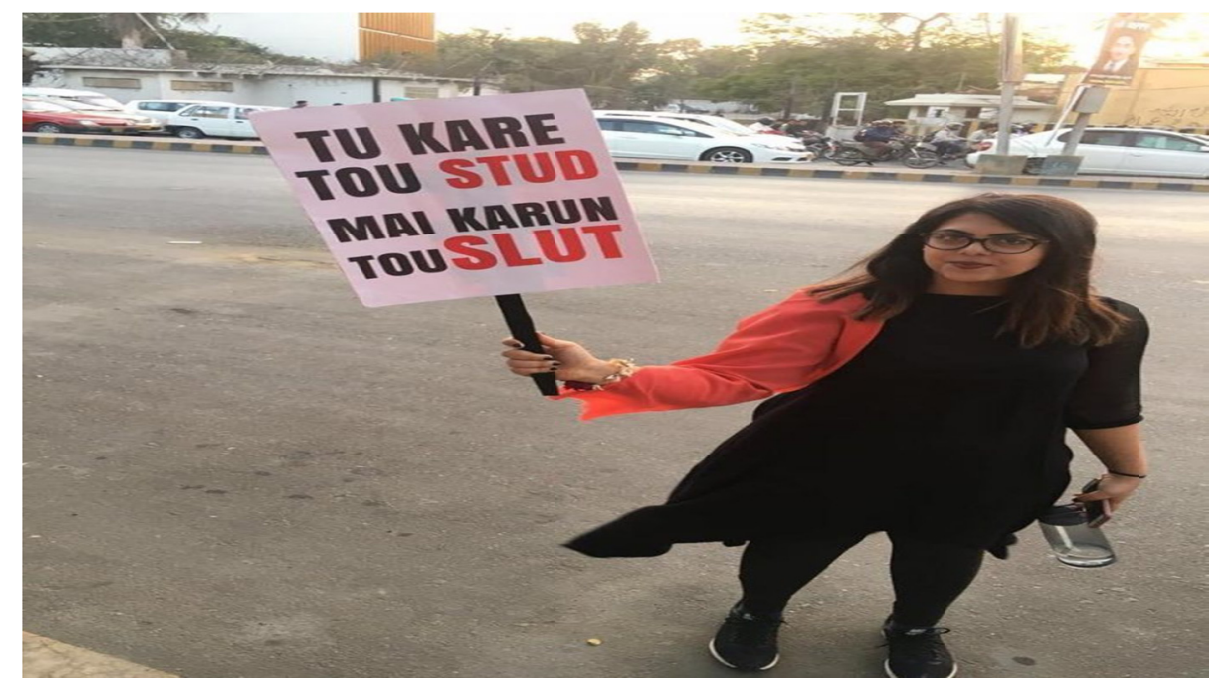

Figure 4. Tu kare tou stud

\section{Analysis}

The poster (Figure 4) is in a girl's hand and transliteration technique used in the text. The word 'stud' and 'slut' are in red color while the whole text is in black color and they are the focus of the text. It is an informal term, usually use for men who are sexually attractive while the 'slut' is an ethnic slur used for women who have no moral character. There is a use of a rhyming scheme in the text. The text can be interpreted as if a man in society does something that is against cultural boundaries and limits then he is someone who is physically attractive and stud but if a woman does the same thing she is labeled as characterless who do not have any moral values. In Pakistani society which is truly patriarchal, and man considers as the head who controls everything. If a man does something unethical or out of sociocultural context then it's not a big deal but if women do that it is considered as the fall of moral values. Mills (2008) argues that the women of the third world country faced the issues of feminism at two 
level one they are females and second, they are females of third world countries (as cited in Darweesh \& Ghayadh, 2016)

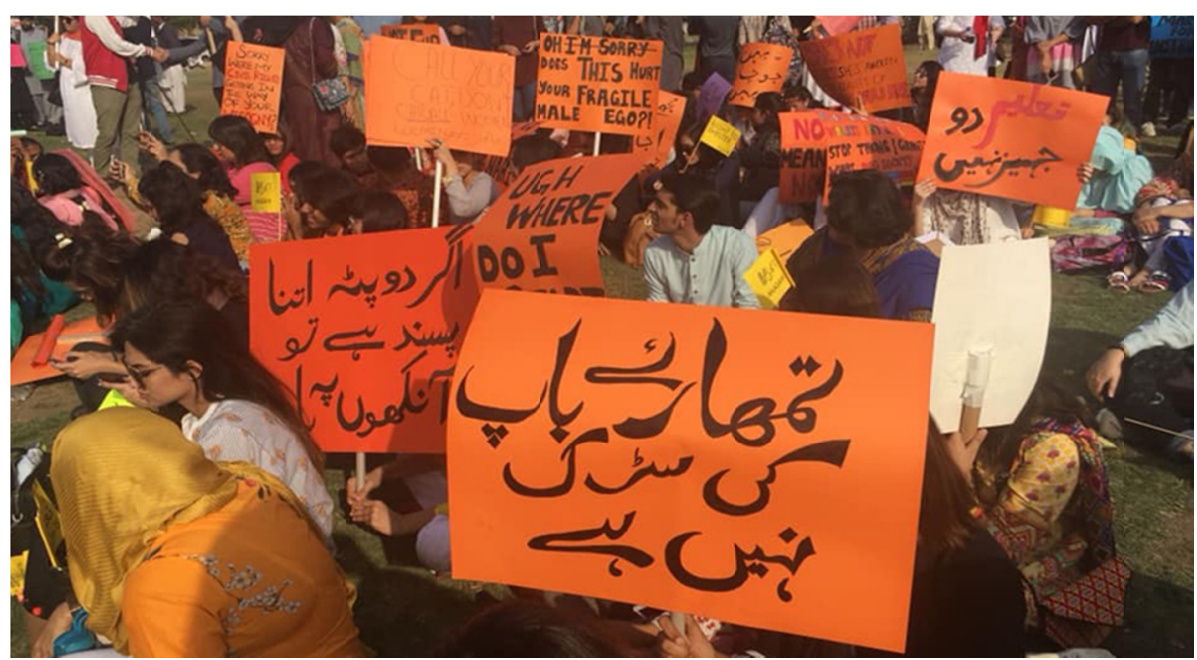

Figure 5. Tumharay baap ki sarak nahi hai

Note. Main text: Tumharay baap ki sarak ni hai; Translation: This road does not belong to your father.

\section{Analysis}

The text is written in the Urdu language and the message is written in black color. The use of the word 'your father' represents the authoritative manner of text. The text can be interpreted as in Pakistan the kids most likely to use the name of their father to show authority. So, the poster can be interpreted as that this road does not belong to them. In Pakistani society, the male mostly has views that women should not come on the road and should not drive. They have authoritative behavior about the roads belong to them.

The article explains the role of media in displaying the ideologies of society and culture that most of the slogans of Aurat March are against the values and traditions of society. Women displayed themselves on roads and streets and most of the people who marched were unaware of the real problems of women.

\subsection{Analysis of Article 3}

The 3rd article for analysis is taken from ARY news. The title of the poster is "Aurat March kay wo posters jo viral naa ho saky" (trans. Women March posters that couldn't get viral). The text of the title is in the Urdu language. Interpretation of the text is that there were so many posters in the Aurat March some of them were so thriving and got viral in media while others couldn't get viral. The slogans of the poster were the reason for their getting viral in the media. In Pakistani culture, media plays a vital role in highlighting things and making them prominent. It depends upon the media what kind of news it is promoting. The posters of Aurat March that got viral somehow got negative attention. We can support the comments with Fairclough's (2001) arguments that the ideology of the writer cannot be effective if the writer ignores the social context.

The poster which couldn't get viral, they are the following: 


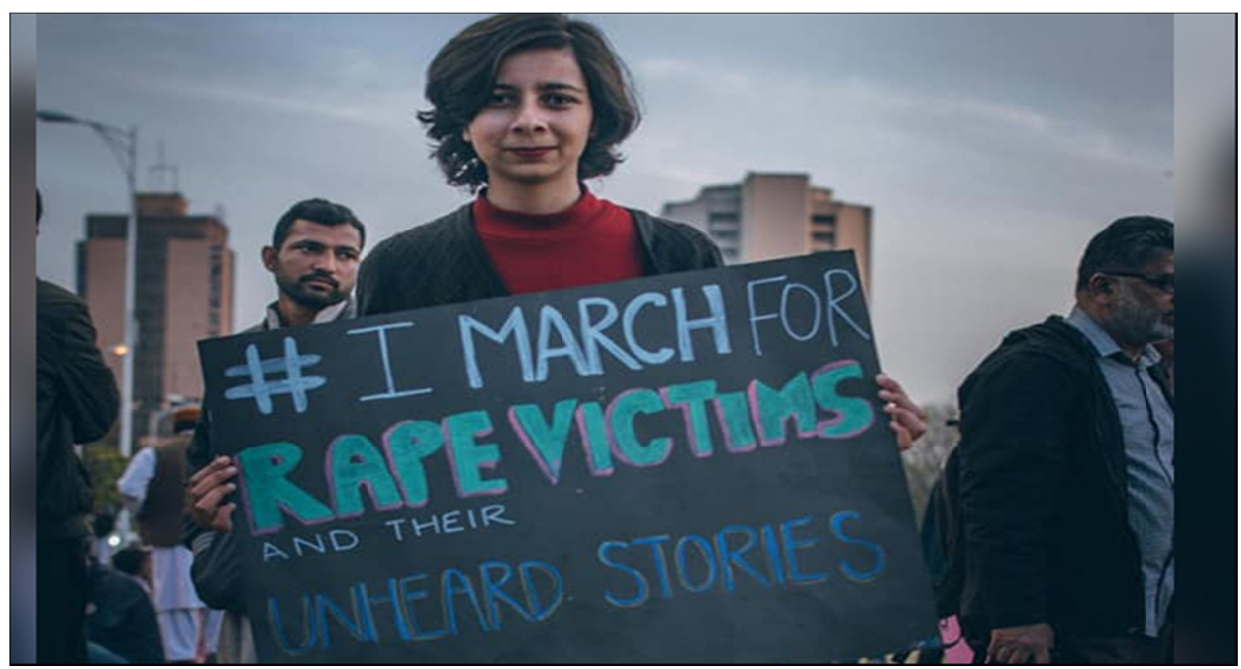

Figure 6. I march for victims

\section{Analysis}

A girl (in Figure 6) is holding the poster. The poster in black color while the text written on it is in blue. The whole text is bold while the word "rape victim" is capital ad bold to draw the attention towards the subject matter. The use of the pronoun 'I' represents self-representation, there is the use of the hashtag (\#) at the start of the slogan which tells about that this matter is important and should be promoted. The rape is carried out against a person without that person's consent. It can be physical force, abuse, coercion, etc. The text interprets that there are so many rape victims in Pakistan whose stories are unheard, they must be heard and understand. There is cultural representation in the text that if someone gets raped specifically women they are mostly silenced by society. In society, if the victim speaks about their suffering and story, it is thought to be a shameful act. Society mostly unheard their stories. They are neglected on many levels. This woman is marching for rape victims which is one of the most significant issues, but this poster couldn't get viral on media.

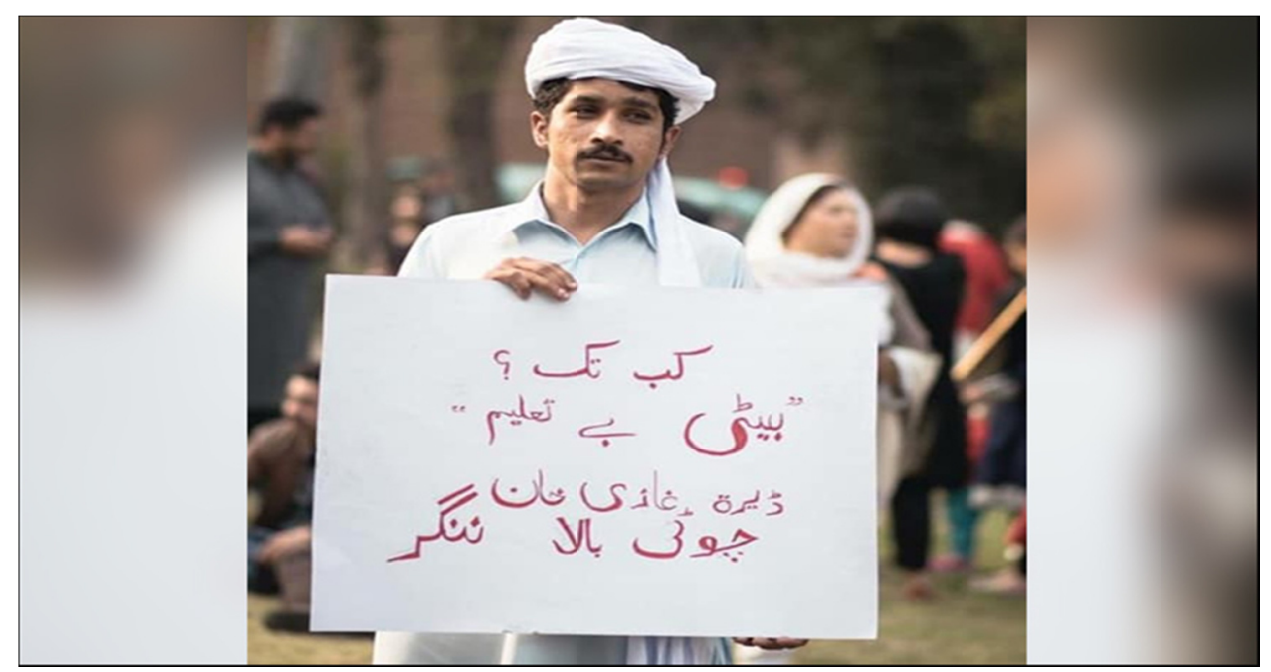

Figure 7. Kab tak? Beti be taleem

Note. Main text: Kab tak? Translation: How long? Main text: beti by taleem, translation: keeping daughter uneducated. Main text: Dera Ghazi Khan (choti Balanagar), translation: Dera Ghazi Khan (choti Balanagar).

\section{Analysis}

The text of the poster (Figure 7) is in the Urdu language. The poster is in white while the message is written is in 
red. This poster is significant because a man is holding a poster in Aurat March. There is the use of rhetoric questioning, and the location of the place is also mentioned. The posters interpretation is that there were men also present in the Aurat March. The focus of this is the education of daughters. And how women's education is not taken as a priority. The poster represents different socio-cultural aspects. Choti Balanagar (Dera Ghazi Khan) is a small town in Pakistan. A man from there holding a poster about women education. In Pakistan, the education of girls is not taken seriously mostly in small towns. The society takes women's education as a secondary thing. The poster highlights the importance of the education of women.

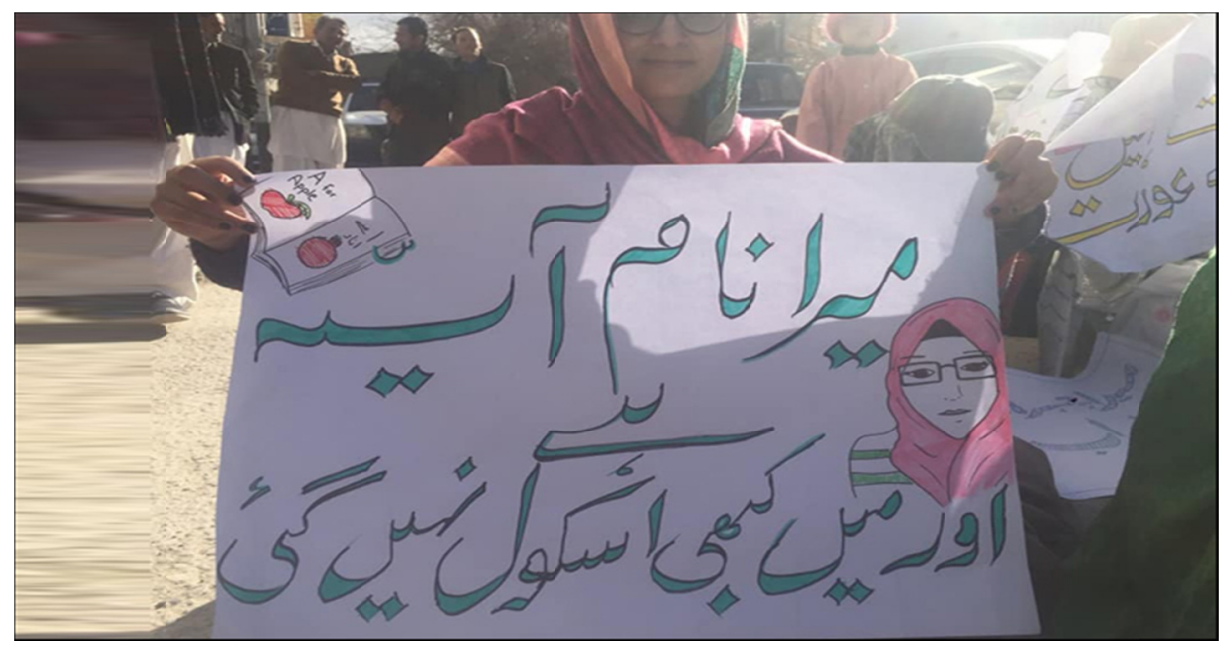

Figure 8. Main kabhi school nahi gyi

Note. Main text: Mera naam Asiya h or main kbhi School nhi gai. Translation: My name is Asiya and I never went to school.

\section{Analysis}

The color of the poster is white while the message written on it is in green color. the poster is written in the Urdu language. There is also a picture of a book and a grown girl. Imagery is used to show the message. The name of the girl is Asiya and it is used for self-representation of herself. The message is interpreted as a grown girl who never went to school and never had education, because of society's views about women's education. It represents cultural thoughts. There are so many barriers in the girl's education and some families don't even believe in educating their women. Even though the female population is more than male in Pakistan, a girl's education is not given primary importance. The message in this poster is like the above poster in which man talks about women's education, that women's education should be given primary importance because they can help in the socio-economic development of the country. The girl holding the poster indicates the main issue of society about the lack of education, especially in girls. This represents the ideology of how society thinks towards the education of girls.

These are the posters of Aurat March which couldn't get viral on media. This article shows how media plays its role by using its power, which can create or change public opinion. This shows that media have the authority to make things viral, so it depends upon media that what kind of news it wants to promote.

\section{Discussion and Conclusion}

Based on data analysis, it is concluded that media can represent and construct different socio-cultural ideologies. This study has investigated the three different articles that reported the same event using language from a sociocultural point of view. The study has shown that the use of language in the media can indicate underlying ideologies by reporting and reshaping articles in different ways. Fairclough's (Fairclough, 2001) model of critical discourse analysis is useful in the analysis of articles to define the relationship between language use and ideologies. The study aimed to identify the role of media in the representation and construction of different socio-cultural ideologies. Firstly, the researchers have identified the ideology behind Aurat March 2019-2020 through the media discourse.

Then, the researchers have provided the analysis under the examination of articles and posters through critical discourse analysis. It is concluded that the media uses its power and language in creating different ideologies, however, the impact of its ideologies based on the feedback of the concerned society, such as the impact of Aurat 
March is negative due to the massive negative feedback from the society of Pakistan.

In conclusion, the researchers have analyzed three articles, that have been presented the role of media in representing ideologies. In the first two articles, the ideologies constructed by media were negative about the specific event (Aurat March) and the third article also has portrayed the role of media negatively because all the posters that couldn't get viral on media had social values and gave a positive image of Aurat March. Overall, the media represented Aurat March negatively. To summarize, despite the positive benefit of information sharing media enables people to create false identities and ideologies. It is believed that media uses its power to create and change the public's belief through the power of language, but it is not possible all the time if the media unable to understand the social context then the feedback can come negatively.

\section{References}

Aazam, F., Baig, F. Z., Baig, T., Khaliq, S., Azam, A., Shamshad, S., \& Aslam, M. Z. (2019). A Critical Discourse Analysis of 'Fire and Fury: Inside the Trump White House' by Michael Wolff. International Journal of English Linguistics, 9(4), 192-199. https://doi.org/10.5539/ijel.v9n4p192

Akhtar, S., Baig, F. Z., Aslam, M. Z., Khan, T., Tayyaba, S., \& Iqbal, Z. (2020). Code-Switching and Identity: A Sociolinguistic Study of Hanif's Novel Our Lady of Alice Bhatti. International Journal of English Linguistics, 10(1), 364-371. https://doi.org/10.5539/ijel.v10n1p364

Althusser, L. (1971). Ideology and Ideological State Apparatuses. New York: Monthly Review Press.

Baig, F. Z., Umer, S., Aslam, M. Z., Razaq, M. S., Khan, S., \& Ahmad, A. T. (2020). Humor as Monotony Breaker in Funny Ads: A Multi-Modal Discourse Analysis of Ads of Pakistani Ufone \& Jazz Cellular Companies. International Journal of English Linguistics, 10(1), 69-80. https://doi.org/10.5539/ijel.v10n1p69

Baig, F. Z., Yousaf, W., Aazam, F., Shamshad, S., Fida, I., \& Aslam, M. Z. (2019). Power, Ideology and Identity in Digital Literacy: A Sociolinguistic Study. International Journal of English Linguistics, 9(2), 252-264. https://doi.org/10.5539/ijel.v9n4p252

Darweesh, A. D., \& Ghayadh H. H. (2016). Investigating Feminist Tendency in Margaret Atwood's "The Handmaid's Tale" in Terms of Sara Mills' Model. A Feminist Stylistic Study. International Journal of English Language Teaching, 4(4), 26-39. Retrieved March 7, 2020, from http://www.eajournals.org/wp-content/uploads/Investigating-Feminist-Tendency-in-Margaret-Atwood

Fairclough, N. (1995). Media discourse. London, England: Edward Arnold. https://doi.org/10.1177/136754949800100209

Foucault, M. (1979). Discipline end Punish: The Birth of the Prison. Harmondsworth: Penguin. Retrieved March 1, 2020, from https://monoskop.org/images/4/43/Foucault_Michel_Discipline_and_Punish_The_Birth_of_the_Prison_197 7_1995.pdf

Foucault, M. (1984). The Order of Discourse. İn M. Shapiro (Ed.), Language, and Politics (pp. 108-138). London: Blackwell.

Gerbner, G., Gross, L., Morgan, M., \& Signorielli, N. (1986). Living with television: The dynamics of the cultivation process. In J. Bryant \& D. Zillman (Eds.), Perspectives on media effects (pp. 17-40). Hillsdale: Lawrence Erlbaum Associates. Retrieved March 7, 2020, from http://www.sciepub.com/reference/30985

Happer, C., \& Philo, G. (2013). The Role of the Media in the Construction of Public Belief and Social Change. Journal of Social and Political Psychology, 1(1), 321-336. https://doi.org/10.5964/jspp.v1i1.96

Izadi, F., \& Saghaye-Biria, H. (2007). A Discourse Analysis of Elite American Newspaper Editorials: The Case of Iran's Nuclear Program. Journal of Communication Inquiry, 31(2), 140-165. https://doi.org/10.1177/0196859906298073

Mahfouz, A. (2013). A Critical Discourse Analysis of The Police News Story Framing in Two Egyptian Newspapers Before January 25 Revolution. European Scientific Journal, 9(8), 309-332. Retrieved March 4, 2020, from https://eujournal.org/index.php/esj/article/view/897/940

Mahmood, M., Javed, S., \& Mahmood, R. (2011). A critical Discourse Analysis of The News Headlines of Budget of Pakistan FY 2011-2012. Interdisciplinary Journal of Contemporary Research in Business, 3(5), 120-129. Retrieved March 7, 2020, from https://journal-archieves8.webs.com/120-129.pdf

Mills, S. (1995). Feminist Stylistics. London \& New York: Routledge 
Mills, S. (2008). Language and Sexism. Cambridge: Cambridge University Press.

Montgomery, M. (1996). An Introduction to Language and Society. London: Routledge. https://doi.org/10.4324/9780203130292

Montgomery, M., \& Feng, D. (2016). 'Coming up next': The discourse of television news headlines. Discourse \& Communication, 10(5), 500-520. https://doi.org/10.1177/1750481316659397

Sabir, M., \& Kanwal, N. (2018). Norman Fairclough's model as a research tool in the critical discourse analysis of Robert Frost's poem Fire and Ice. Journal of Social Sciences, 1(1), 83-99. Retrieved March 4, 2020, from http://uwjss.org.pk/downloads/v1/issue1/010106.pdf

Sibtain, M., Aslam, M. Z., Khan, A., Khan, M., Atiq, M., \& Bhatti, H. (2020). Rhetorical and Persuasive Strategies Employed by Imran Khan in his Victory Speech: A Socio-Political Discourse Analysis. International Journal of English Linguistics, 10(2), 249-356. https://doi.org/10.5539/ijel.v10n2p349

Thompson, J. B. (1984). Studies in The Theory of Ideology. Cambridge: Polity Press.

Wodak, R. (1999). Critical Discourse Analysis at the End of the 20th Century. Research on Language and Social Interaction, 32(1-2), 185-193. https://doi.org/10.1080/08351813.1999.9683622

Wodak, R. (2002). Aspects of Critical Discourse Analysis. Zeitschrift für Angewandte Linguistik, 36, 5-31. Retrieved from http://citeseerx.ist.psu.edu/viewdoc/download?doi=10.1.1.121.1792\&rep=rep1\&type=pdf

\section{Copyrights}

Copyright for this article is retained by the author, with first publication rights granted to the journal.

This is an open-access article distributed under the terms and conditions of the Creative Commons Attribution license (http://creativecommons.org/licenses/by/4.0/). 